\title{
Entrepreneur of the Regime Change - the Fusion of the Hungarian Economy with Organized Crime
}

\section{Tamas Bezsenyi}

busojaras@gmail.com

\section{Doi:10.5901/mjss.2015.v6n2s2p219}

\section{Abstract}

In recent years the Hungarian administration of justice trialed some of the most famous murder cases of the 1990's which were contract killing between organized crime groups. These trials brought up many new information about the life of organized crime gangs and given a better opportunity to criminologist to understand the recent activity of the organized crime gangs. I wrote my thesis about how organized crime successfully survived the crisis of the regime change. The following research based on a tight cooperation with Pest County Police Headquarters where I analyzed criminal files about organized crime gangs after the regime change. The main question of the research was: what sociological and economical factors contributed to the strengthening of organized crime In Hungary? Where can we discover the responsibility of the state? How state regulation affected organized crime? The present days organized crime roots from illegal criminal groups existed in the socialist period. Thanks to the liberal economic reforms in 1981 the second economy had a great economic potential during the socialist period. Organized criminal groups often invested in private sector thus corporate crime became linked to organized crime. Due to their better economic conditions the criminal networks could establish different kind of private ventures, like restaurants, pubs or tobacco shops. After the declaration of democracy many organized crime networks took advantage of regulatory gaps. They preserved their status and informal capital from the second economy. Due to the economical change the new entrepreneurs informally forced to borrow capital from organized crime groups, or they used these group's money to recover their debts. They could not turn to court because of their illegal transactions. Other organized crime networks misused government subsidies and created semi-firms, which could operate successfully due to the problems of state control. My research seeks to show that during the third Hungarian Republic from the 1990's organized crime groups have worked with the help of entrepreneurs. Due to the economic crisis of 2008 and the emergence of political extremism the organized crime groups became number one public enemies, who are again using the same methods what were successful during early 1990's. A kind of semi-legal market and entrepreneurship has developed since 2008.

Keywords: Entrepreneur, Regime Change, Hungarian Economy, Organized Crime

\section{Introduction}

The political-economic system change of 1989/1990 effected Hungarian organized crime syndicates as well. With the change of legal frameworks, it became harder for authorities to keep track of organized criminal activities. Society at large started fearing the unknown, since during socialism the entire concept of organized crime was terra incognita for the majority. Through a notorious case, I wish to explore how organized criminal activity transformed as a result of the system change.

I wish to prove, that criminal successfully exploited the transformational crisis and the ensuing legal loopholes caused by the system change. János Kornai identified the collapse of former export markets as one of the symptoms of this transformational crisis. My research shows, that this was indeed one of aspects of the system change that organized crime syndicates successfully exploited. Other important causes of the transformational crisis included the low efficiency of bureaucracy, the underdevelopment of the financial markets and the persistence of strong grey and black economies.

In the Soviet Union "The chaotic transition of the Soviet Union to the market economy created the conditions for the widespread penetration business activities in Russia... by organized crime." According to sociologist Manuel Castells (2007: 200), this process helped intensify legal and illegal trading activities with the post-soviet area. In a 1994 report, the Center for Social and Economic Analysis - a background institution of the Office of the President of Russia - estimated that around $10 \%$ of economic actors in Russia were involved in illegal economic activities, with illegal transactions equaling $20 \%$ of the capital worth of the regular economy (Izvestiya 1994).

Through a Hungarian example, I wish to highlight, that throughout Eastern Europe, informal ties and legal or illegal business models developed throughout socialism remained predominant in these newly emergent market economies. I believe it to be telling, that many of the people killed during the mafia vendettas of the 90s in Hungary were businessmen 
involved in either legal or semi-legal activities, through which they were making serious profits (Barnóczki - Prókai 2012). The Russian newspaper Kommersant practically ran an obituary on Hungarian businessmen murdered in mafia vendettas (Goldman 1997.).

In this paper, I wish to show how the new capitalists that emerged following the system change, fused together with the newly emerged organized criminals. I wish to prove, that Mr. József Stadler was and would have been a successful businessman without associating himself with criminal elements. I also wish to refute the popular perception perpetrated by the media - that Mr. Stadler was nothing more than a tax evader: such an interpretation of his activities greatly oversimplifies the truth. The reason this perception emerged, was largely due to the fact that economic journalists of the day, did not have a profound understanding of the dynamics of the new, capitalist market. Indeed, the quality of such investigative journalism remains questionable even today. It should also be underlined, that the journalists that took issue with Mr. Stadler, almost exclusively focused on the uncertain political aspects of the case (Index 2001), although given the evidence that was at their disposal at the time, they could and should have been able to see the much more tangible interests motivations behind the dubious entrepreneurs actions. ${ }^{1}$ József Balla points out, that court cases of rural districts, are primarily taken-up by freelance journalists, who feel pressured to produce entertaining articles, in order to sell them to newspapers. From such an infotainment perspective, ${ }^{2}$ the twenty years old girlfriend and the oil painting of the entrepreneur proved to be the most important aspects of the case. In order to dig-up the juicy details, such journalists endeavored to build close relationships with accomplices of Mr. Stadler. For all practical purposes, this means that such "cooperation (however we may judge it)" determines "the angle the readers of the story get the following day, that is to say, the aspects of the case that are thrust into the public eye"(Ballai 2001a). We should however mention that even information derived from such information, may produce factual errors, even in extensively researched books, dedicated wholly to the subject (Ambrus 1995). ${ }^{3}$

\section{Penetration of Organized Crime into the Economy}

I hypothesize that following 1990, organized crime syndicates underwent a qualitative change due to the transformations in the economy and the legal system in Hungary. This is why my research only extends only until September 15th 1997, when the legislator instituted the term of 'organized crime syndicate' into the penal code with the LXXIII. law. Examining the timeframe of 1980-1990 is especially important from an organized crime-criminology perspective, since the effects of today's organized crime activities are hard to fathom. This is why taking a historical perspective is more justified. There is much to explore, highlighted for example by the fact that many of the vendettas of the 90s are still shrouded in uncertainties.

The case of József Stadler - an entrepreneur from Akasztó - became one of the most iconic cases of the 90s, calling the attention of the wider public to the deficiencies of the newly emerging market economy in Hungary. Due to the intensification of vendettas and other high profile economic crimes (Globex, Postabank-case) during the second half of the decade, the public forgot the lessons that could have been learned from the Stadler case. Journalists and other experts tended to focus on later crimes in their books (Mong - Vajda 2009) or articles (Diós 2009).

Through a series of interviews conducted with police detectives, it quickly became apparent that for the reasons mentioned above ${ }^{4}$, the case of the entrepreneur from Akasztó - along with his motivations, and the criminal techniques applied - quickly faded from the agendas of criminal justice conferences and symposiums as well. In the meantime, the case file grew so thick, that involving new detectives in the investigation became increasingly difficult, and eventually impossible. Just bringing new officers up to speed through a detailed overview of the files would have taken several weeks at first and would have later taken several months at least. According to one of the detectives, one of the housesearches alone yielded several hundred kilogram bags of documents, occupying $40 \mathrm{~m}^{2}$ of storage space 5 . Undoubtedly, one of the most ironic elements of the case is the fact, that the case documents - totaling several tons - are nowhere to be found. They are not in the police archives, and according to my inquiries, they are not in the Hungarian historic archives either. By all accounts, it seems that they have been scrapped. ${ }^{6}$

Throughout my research, I conducted interviews with retired and still active police officers - 4 all together, who

\footnotetext{
${ }^{1}$ Refreshing exception József Ballai, who had done extensive investigative work in connection with the Stadler case.

2 The information (information) and entertainment (entertainment) English nouns flattening of the resulting concept.

3 This kind of suspicion already appeared earlier works of Ambrus. See: Zelei Miklós: Még egy kis Ambrusológia. Beszélő, 1990/ 1., 3.

4 Interview with "B. M." police colonel 2013. 02. 24.

5 Interview with "B.I." retired police colonel, 2013.03.31.

6 Interview with "B. M." police colonel 2013. 02. 24.
} 
were investigated the Stadler case. These proved immensely useful to fill in the gaps left by the case files, and in complementing the information found within them as well. Although I followed the chronological order of the case during the interviews, in order to be able to uncover new pieces of unexpected information, I employed a semi-structured interview structure (Kovács 2007). The success of the methodology used, is largely dependent on the interviewees level of trust towards the interviewer. Most of my subjects wished to stay anonymous. In order to avoid possible "interviewtraps" I have used the Gabriele Rosenthal (2006) method, treating all interviews as a related narrative, and taking notes on the meta-communicational signals of the subjects, interpreting the entirety of the interviews.

\section{Difficulties of Investigating Organized- and Economic Crimes}

In the following, I will review the effects that the political system change of 1989 had on the police force's relation to investigating economic crimes. By doing so, I hope to shed light on the true nature and extent of the influence of Mr. Stadler in this process. The following analysis aims to showcase that the entrepreneur from Akasztó was - and would have remained - a profitable businessman without committing economic crimes. This assertion is also closely related with the rejection of the assertion that the main source of illegal revenues of Mr. Stadler came from VAT fraud. The fact that the media persistently identified him as a VAT fraudster is due to several things.

For one, journalists of the day were not particularly well versed in the different methods of economic crimes. Adding to this was the misguided perception of several police officials. At the time of the system change, the social ownership protection of the police departments (TT - as how the police informal language referred to the social protection of property) were on the verge of being closed down, and with the dawn of the market economy, several high ranking police officers advocated that these not be transformed into general property protection departments. In his testimony in front of the Parliament's Oil Committee in 2000, brigadier General Gerenal Ernő Kiss said the following: "some police leaders voiced strong opinions, that in a market economy, there was no need for any economy-related police work." "This quote allows us to deduce, that some prominent police officials of the day, had an overly optimistic, vulgarized understanding of Adam Smith's invisible hand theory. Their reductionist premise suggests, that following the creation of a capitalist market economy, committing economic crimes that were perpetrated during the time of majority state ownership and incumbent state companies would become senseless.

The lack of understanding surrounding the nefarious activities of Mr. Stadler was compounded by another issue. On the 5th of January, 1990 prominent politicians from SZDSZ and FIDESZ brought charges against the State Security Service of the Ministry of the Interior, for illegally spying on opposition parties and civil society initiatives. Although, according to the constitutional modification of October 23, 1989 such methods were banned. However, the official police charges included incriminating documents, like Report 219. prepared by József Végvári, group leader of the Ministry of Interior's Interior Security group BM III/III-7. on the $10^{\text {th }}$ of November 1989. The opposition parties held a press conference in the Miner's Cinema after they pressed the charges. Here they presented other reports from the same group. Reports from December the $6^{\text {th }}$, the $20^{\text {th }}$, and the $22^{\text {nd }}$ contained a significant amount of information attained by covert methods (phone taping, violation of private correspondence, informants). As an immediate consequence of the ensuing scandal, Minister of the Interior István Horváth resigned his office at the end of January of 1990 (Dunagate report 2015).

As a result the of all the public attention the case was getting, high ranking police officials felt compelled to indiscriminately disband informant networks, including assets working in the field of criminal justice. ${ }^{8}$ This decision proved to be detrimental. Without assets, carrying out operative investigations proved to be nearly impossible. Investigations regarding economic crimes took a particularly heavy blow. During the transition period many of these crimes were committed against the state its self. ${ }^{9}$ In many cases, the damages caused were less apparent and thus went unnoticed. Counter to the pre-1989 mentality, the Criminal Code of the day did make it possible (in chapter XVII) for economic crimes to be committed against private entities, not just the state and its companies. Informally, however, the state remained at the center of the authorities' perception of economic crimes. On the one hand, the newly established private

\footnotetext{
${ }^{7}$ Minutes of the Parliementary investigative committee created to investigate any possible links between the oil business and organized crime. 2000. 10 o'clock Monday, October the 30th, meeting held at meeting room number 61 of the Parliament, accessible online at: last download: 2013.05.15 http://www.parlament.hu/biz36/olaj/v006-021.htm

8 Interview with "N.L." retired police colonel, 2013.04.17

9 Interview with "B. M." police colonel 2013. 02. 24.
} 
sector relied largely on the process of privatization to gain access to equipment that was once state property. ${ }^{10}$ On the other hand, through the criminalization of tax avoidance, the state retained its presence in the market economy.

At the time, the National Police Department ${ }^{11}$ (ORFK) did not have a separate property damage department. The Budapest Police Department's (BRFK) ${ }^{12}$ property damage department functioned as an operative entity only, with concrete investigations being conducted by a general investigative department. County police departments had property damage departments, which conducted both operative and investigative work. However, without informants, conducting meaningful operative work became impossible (Korinek 2015).

The decision not to transform the departmental structures of the police force to better suit the changing economic realities - i.e. by not converting the communal property damage departments into property damage departments, and the decision to disband the informant networks - lead to a drastic increase in economic crimes like fraud, embezzlement or malfeasance.

Both Brigadier General Ernő Kiss and Police Colonel László Tonhauser emphasized that the above mentioned decisions effected economic crimes related detective work the most. In the case of a homicide or larceny case, it is easier to find witnesses and the media can be used to aid the investigation to greater avail. In the case of economic crimes ${ }^{13}$ however, insider information or turned witnesses are many times the key of resolving a case, with the media playing no role in the investigative process. This is due to the fact, that intricate economic crimes are much harder to present in an intriguing way toward media consumers. ${ }^{14} \mathrm{It}$ is common knowledge that many crime-investigation related movies and series portray misrepresent the actual nature of detective work to make it more sellable, economic type investigation, however is never even portrayed. ${ }^{15}$ Over the past twenty years, a considerable amount of investigative journalism has been focused on introducing these crimes into the perception of the wider society. Even so, the transgressions of politicians and other public office holders are those that are mostly present in the media. Economic crimes (domestic and transnational alike) committed by non public figures mostly fly under the radar - save very few exceptions. ${ }^{16}$

The realization and acknowledgement of these processes calls for the reinterpretation of the statistical data presented in Mihály Tóth's research paper: Market Economy and Criminal Law. Tóth's (1995: 4-5) data shows, that the number of crimes committed per year rose from approximately 100.000 in 1974 to over 400.000 in 1994. The most significant increase took place following the transition to the market economy. Between 1986 and 1988 the yearly number of crimes known to the authorities was 180.000 on average. This number steadily increased: to 225.393 in 1989 , to 341.061 in 1990, to over 400.000 in 1991 and to 447.215 in 1992. According to Tóth's (1995: 4-5) data, the number of economic crimes stayed more or less stagnant at 8000/year all throughout this period. As seen from the article, the author had difficulties explaining this stagnation, saying that two-thirds of these crimes were tariff and foreign exchange related, who's: "number was constant (or at least, the amount of money spent on uncovering these crimes was)" (Tóth 1995: 5). However, this does not explain, why only the number of economic crimes stagnated, and it disregards the fact, that other departments or segments of the police force were working at full capacity as well. Tóth's argument is more useful in explaining why the number of economic crimes decreased by 1994: the opening of the boarders and the transformation of the economy brought about new customs regulations as well. At the end of his explanation, Tóth suggests that the authorities are lagging behind criminals when he points to the fact, that several areas of criminal behavior were ignored by the police force. He brings the deficiencies of the 1994 criminal statistical handbook as an example. Although profiteering had been taken out from the criminal code, and the definition of unfair price increasing had changed significantly, the handbook still included the pre-system change categories (Tóth 1995: 7).

The lack of restructuring the police force following the 1989 transition, as outlined above seem like the most

10 In the current tax-law (Law C. of 2000) the basic accounting equation makes it possible to describe a company's accounts by looking at the changes in tools and financial instruments. (Losonczi Csaba - Magyar Gábor: Pénzügyek a gazdaságban. Juvent Kiadó, Budapest, 1996. pp. 415-417.)

11 Hierarchically the highest national body of law enforcement in Hungary

12 The main police department of Budapest.

${ }^{13}$ For the sake of simplicity, I define economic crimes as those that according to the Hungarian penal code, may be committed against property, since fraud and embezzlement investigations are conducted by property protection departments regardless of their placement in the penal code.

${ }_{14}$ One of the refreshing exceptions from the past years is the series produced by criminal investigative journalist David Simon, entitled: "The Wire", which chronicles crime fighting in Baltimore.

${ }^{15}$ Enough to emphasize the complaints of police officers who mentioned several times to the media that the citizens demand from them the techniques and methods what they saw in the TV. Fekete Gy. Attila: A magyar nyomkeresők bealszanak a CSI-on. Népszabadság 2009. 11. 28. (http://nol.hu/lap/hetvege/20091128-nyomkeresok)

${ }^{16}$ Most of the exemptions may be found in print or online media forums, like the Hungarian weekly HVG, or Átlátszó.hu. 
plausible explanation for this lack of increase in the statistics. The anachronistic language used by Tóth in his analysis and the outdated problem-understanding behind the statistics totally disregard the fact of the system change. This gives a further indication of the ill preparedness of the police force of the day.

According to Tóth, the radical decrease in economic crimes in 1994 does not indicate a "spectacular improvement" (Fekete Gy. 1995: 1) as seen by the frequency of stories of economic crimes being published in the press. Since many crimes remained hidden, Tóth only aimed at estimating the approximate share of economic crimes in relation to other crimes, to see if their importance increased or decreased. Partly based on the press material published by a investigative journalist, who interviewed the director of ORFK's criminal unit (Fekete Gy. 1995: 1), Tóth concluded that the weight of economic crimes had increased. In the frontpage article of Attila Gy. Fekete, the journalist interviewed the criminal director of the time, Antal Kacziba, who claimed that counterfeiting (Vegeta spice, Herendi Chinaware) was one of the major threats during his tenure. For the latter, unauthorized loans VAT refunds, fake collateral certificate recorded were the biggest issues. At the request of a political TV program ("A Hét") a Hungarian public opinion research firm, Sonda Ipsos made a poll, in which they found that according to two-thirds of the respondents the reason for growing phenomenon of economic crime was associated to regime change and the incomplete nature of economic rules (Fekete Gy. 1995: 6).

So while the detection of these crimes by police decreased during the first half of the $90 \mathrm{~s}$, according to the police officer cited by Tóth, and according to other public statements made by police leaders - that I will refer to later - the actual number of economic crimes experienced an unprecedented boom.

In 1996, Antal Kacziba, then deputy state secretary of the interior was already talking of the "explosive increase" of fraud and bankruptcy crimes, owing to the introduction of new legislation in 1994-95 relating to public procurement, bankruptcy crimes and protection of intellectual property rights. The new laws lead to an increased role of property protection departments in unveiling economic crimes. "step by step, previously only rarely used criminal categories "came to life«" (Kacziba 1996: 61).

Enumerating all the reasons for the initial latency of many crimes seems an impossible endeavor. I do however wish to identify the most important reasons. I find it essential to highlight the problems surrounding the capitalist transformation of the economy at large. Capitalist statecraft did not appear instantaneously following the collapse of the Iron Curtain in the post-socialist region of the Soviet Union. The collapse was followed by a transitional phase. Based on empirical findings, the manager-capitalist theory of Iván Szelényi shows that it was the technocratic managers and leaders of ex-incumbent socialist companies whose power and influence increased exponentially in the 90s, and not that of the small and medium entrepreneurs. In a period of low market capitalization, these managers - who mostly went on to lead the privatized equivalents of the socialist incumbents - could not create a stable capitalist market overnight. Their main assets were their informal contact networks, which they used as investable and transformable assets. During the socialist period the ownerships could be seen as a vacuum based on Pavel Câmpeanu, therefore József Böröcz (1992) emphasized the informal practices of the regime change. The system of mutual favors also played a very important constituent role in this world. These aspects of the system are stressed by Endre Sik (2012) as well when he talks about the system-specific processes of the system change. The joke of the day - cited by Szelényi (1995) - illustrates this situation: it is known, how fish stew (socialist state) can be made from an aquarium of fish (capitalist state), however the method of making fish out of fish stew is as of yet, unknown to man.

The next reason that needs to be mentioned is the outdated justice system of the day. In 1994, Tóth pointed out that it is often the case with new crimes, that they are interpreted totally differently by the prosecution and the police authorities. At the time, it was often the case, that crucial facts of the case were only established well after the initial investigative processes, since only qualified experts, like accountants were able to certify these facts. In relation to this phenomenon, Tóth cites an article February the $7^{\text {th }} 1995$ from the daily Népszabadság. The title of the article is already telling: "A lack of experts is complicating investigations into economic crimes". Since then, experts in this field are held in much higher regard and their pay has increased significantly. Indeed, the field has become so lucrative, that there are many fraudulent "experts". The phenomenon is well chronicled by an article in the $70^{\text {th }}$ edition of Criminology Review written by István Jávor and Dávid Janics (2012), entitled Corruption in the courthouse and the economy.

Another good example is István Jávor's article (Corruption in the judiciary and the economy), which deals with the issue of abusing the system of "experts". Mihály Tóth in 1994 supported the usage of experts, especially on the side of the defense. In contrast Jávor (2011) found that the misuse of the experts changed the aim of the whole trial, facilitating endless polemics. Therefore the financial background of the defendant decided the outcome of the trial.

In 1994, Mihály Tóth argued for the extensive use of experts, advocating the defense's right to employ them as well. However, looking at the findings of Janics and Jávor, we may say, that the overuse of experts and their fundamentally different assessment of the same situations has, in many cases, lowered the overall quality of the debate 
in court cases.

Furthermore, it is important to highlight the question of morale and law. Here I am referring to the lack of a strong economic or tax morale. This meant that Mr. Stadler was portrayed by some parts of the media and perceived by many as a folk hero of sorts - this is clearly illustrated by the article in National Sport (2007). Péter Imrédy wrote five volumes on the life of the entrepreneur, entitled "The Stadler Story". The language used by Mr. Stadler in the interviews in the books is simple, peasant like with an almost rustical quality - similarly to the language he used in spoken language, as illustrated by several video interviews (Index 2007). Mihály Tóth lamented the lack of a proper societal moral compass himself, blaming the paternalistic perception of Hungarian society. According to him the extensive amount of written regulations resulted in "arbitrary reinterpretation" of the "everything is allowed that is not prohibited by law (written laws of course!)" norm (Tóth 1995: 23). In other words, the lag of the speed and the unclear phrasing of new regulation in the wake of the political economic system change - and the abundance of legal loopholes - facilitated the blurring between the lines of legality and illegality. Jávor and Rozgonyi (2005: 155-157) described on the basis of level of organizational operation calls this negative legitimacy. While a positive process of legitimation of state bodies accountable to guarantee accountability, while the state administration bodies are not similar to positive action, but in the opposite direction guarantee provided to members of the society, which is an informal, social acceptance level makes the norm violation.

\section{Entrepreneur of the Regime Change}

In order to be able to properly interpret the criminal behavior of József Stadler, it seems useful to consider Antal Kacziba's observations on organized crime. He believes that a prime indicator of the fact, that someone is partaking in organized criminal activity, is the speed of his wealth acquisition - something observable by the extensive usage of luxury items. He also mentions the possibility of laundering money by investing into legal business activities as a possible connection between organized crime syndicates and individuals involved in illicit economic activities. According to Kacziba, this new form of cooperation was brought on by the circumstances of the 90s. Valér Dános believes that these two groups already started cooperating in the 80 s as an unwanted side effect of privatization and as an inner conflict of economic liberalization.

József Stadler started exporting various products to eastern markets from the 1990s, especially to the Soviet Union, and the newly emergent Ukraine and Russia. In police testimonies made in front of the Parliament's Oil Committee, the implications of the dissolution of the Soviet Union were discussed. According to Erno" Kiss: "the penetration of people from various parts of the state institutions into the spheres of economy has started there as well. We have the appropriate connections. Right from the start, we should have done the same. We did not however have the appropriate staff to conduct information gathering operations in Ukraine or even in Russia based out of Hungary."17 Besides the deficiencies caused by the disbanding of the informant networks, State Security's lack of adequate connections with the services of neighboring countries made uncovering trans-boarder criminal networks specializing in economic crimes practically impossible. It is likely that formerly high ranking state officials of the Soviet Union - and other eastern republics - moved to lucrative economic activities without greater difficulties, much like they did in Hungary.

Following the 1991 dissolution of the Soviet Union, many things stayed the same in Russia, many soviet traditions lived on. The Hungarian economist László Csaba makes mention of the ban on bartering, instituted by the Russian government, in order to spur the population to use the official currency (Csaba 1991). The endeavors of Mr. Stadler were also helped by the fact, that the Russian government levied a $40 \%$ tax on profits made off of exported goods. Csaba (1991) describes the economic policies of Yelcin as having a sort of folkloric quality based on poetry and realities. The reason being, that while the political declarations made in the media lead observers to believe that the government was perusing a sound monetary policy, in reality they continued to pursue Soviet style planning cycles (Csaba 1992). Public perception of the so-called "shock therapy" applied in the Russian Federation was, that it was forced on Yelcin by the United States and the IMF (Csaba 1992). According to Claus Offe, Eastern-European societies faced the dilemma of simultaneity, since they had to undergo political, economic and social transformations at the same time. However, the restrictive market economic reforms "only come into effect under pre-democratic conditions" (Offe 1991: 118).

So, the social support that translates into democratic legitimacy was only an illusion. The media at the time, most likely understood this very well, since as Csaba (1991) points out, that the Russian journals of the day were making jokes to the effect, that the Russian leadership didn't even translate the IMF accession requirements into Russian when they

17 Minutes of the Parliamentary investigative committee created to investigate any possible links between the oil business and organized crime. 2000. 10 o'clock Monday, October the 30th, meeting held at meeting room number 61 of the Parliament, accessible online at: last download: 2013.05.15 http://www.parlament.hu/biz36/olaj/v006-021.htm 
joined the Monetary Fund instead they immediately translated the Russian declaration of joining into English. Csaba (1991) believes this to be as much of a folkloric element as the possible adherence to the IMF conditionality, which would have meant a restrictive money supply policy, and the liberalization of trade. Yelcin however applied the exact opposites of these policies. Csaba (1992) however points out that stabilization is less a question of economic theory than one of technical control mechanisms (Csaba 1999). Perhaps this is the reason, that during the Yeltcin period economic stabilization did not happen. According to Csaba, such stabilizations should have consisted of three main elements. First, the fixing of the exchange rate, which in turn would lead to equilibrium between black market and actual market prices. The restriction of the monetary supply would have artificially increased the availability of products. Reforms should have targeted both the expenditure and both the income sides of the budget. However, the reforms that took place in Russia between 1992 and 1996 almost exclusively target only the income side of the budget. Since economic liberalization in Russian took place without the proper stabilization, companies started accounting in USD and Deutschmark. Thus, Mr. Stadler received his income from the Russian market in these currencies as well. Having profits denominated in stable currencies was a big advantage at the time, when economic circumstances were fast-changing. The Russian state did not adhere to the strict monetary controls that it set itself at the time (Ponton 1994).

Gerashchenko once perceived as a strong supporter of the 1991 monetary reform ${ }^{18}$ officially abolished more than 1000 billion ruble's worth of inter-company debts during the summer of 1992. This act, in and of its self greatly helped Russian industry, and especially companies focusing on military production. Of course, this policy resulted in the lasting instability of the ruble, and it hindered the continuation of any reforms to the overall economy. As a result, experts were acutely aware of the fact that the liberal turn in the Russian export policies would have to wait. That, convertible national currencies would not appear, and that inflation would go untamed. History has proven them right (Csaba 1992).

Grigorij Aleksevich Javlinsky, the later leader of the Russian Democratic Party (Jabloko) was strongly influenced by the thoughts of János Kornai and Michael Ellman, thus envisioning a sort of system of national capitalism (Javlinszkij 1994). He discarded the notion of decentralized privatization. According to Tamás Krausz (2003), he did not want to accept a sort of periphery variety of capitalism. This meant, that even though he tried to put a stop to the escape of company executives and managers from state control, he could not. State companies started instituting "double accounting", selling more and more of their products on the black markets. This helps us understand why these companies would have been interested in being officially overbilled by their partners, since they could use such bills in their double accounting schemes. Later on, mid-level economic actors took over the state's control function through their extensive informal networks (Szelényi - Eyal - Townsley 1998).

According to Krausz (2003), Javlisky saw these processes as maffiacapitalism, when instead of the emergence of market mechanisms, a system based on a sort of gambling logic emerges, which proves to be unsustainable due to the penetration of the black market, and the permanent avoidance of paying taxes. Russian liberals did not anticipate the importance of informal connections and the strength of such a culture of resistance to reform (Krausz 2003). Effectively, partaking in this informal economy became the primary prerequisite for anyone wanting to actually do business in the Russian economy at the time.

This meant that making profit became increasingly difficult on these eastern markets. Insider information, well placed informants and the exploitation of the loopholes in the laws were absolutely vital elements of success (Jávor Rozgonyi 2005). Among other things, the financial interventions of Gerashchenko hindered the emergence of a stable market economy. Similarly to the Hungarian situation, there remained several factors that allowed József Stadler to exploit his existing contacts - and to find new ones - to maintain the profitability of his enterprises.

In 1988, József Stadler founded Stadler LLC with an initial capital stock of one million forints. Mr. Stadler was the chief executive of the company from the very start. At first, Stadler LLC only conducted trade within the borders of Hungary, however following the transition, the company quickly expanded to international trade. In the Stadler Story, Mr. Stadler says that he had started out in the 60 s by buying cheap alcohol from various collectives in Bács-Kiskun County, and selling it to neighboring pubs and restaurants at a profit (Imrédy 2008).

In the 80s, Mr. Stadler bought copious quantities of wine from these collectives, which he stored in wine cellars in Pest county until an opportunity to resell them at a profit presented itself. ${ }^{19}$ This kind of activity was illegal, but in the book Stadler frames it, as a perfectly legal business model. However, he contradicts himself later on in the book, when he

${ }^{18}$ By decision of Valentin Pavlov - then financial minister of Russia - a certain amount of ruble's were taken out of circulation, in order to decrease the problems caused by the lack of products. According to the official explanation, the reason for the move was founded in the fight against counterfeit money. (Raddaway, Peter - Glinski, Dmitri: The Tragedy of Russia's Reforms: Market Bolshevism against Democracy. US Institute of Peace Press, Washington D. C. 2001. pp. 273-274.)

19 Imrédy Péter: A Stadler story 1. kötet A kisjuhásztól a nagy felvásárlóig. Kastély-Bor Kft., Akasztó, 2008. pp. 115-117. 
says, that what he was doing could only have been conducted legally by the commercial departments of the collectives. Stadler admits that he made special arrangements with these departments, to have some trucks delivering wine directly to his cellars.

By 1988-89 he he'd established such good relations with the leaders of various collectives, that he already had a good grasp on the workings of the wholesale distribution networks in the country. He started buying alcohol from the factory, and he built a large distribution network, operating with his own trucks. At the time of the system change, the manufacturers and wholesalers that Mr. Stadler had been doing business with got into a tough spot (Paládi 1988). The COMECON formally ceased to exist on June the $28^{\text {th }}$ of 1991 . Several companies lost the markets that they took for granted overnight: the Nagykörös canned food factory the SZOBI fruit concentrate factory, the Köbánya beer factory or the Budafok wine cellar. This meant that Mr. Stadler could buy up their products dirt cheap. In 1990, the coalition Antall government was formed between MDF, KDNP and FKgP. The eastern markets were not overly important for these parties. The infamous "Tavarisi konyec" (it's over comrades!) poster of MDF symbolized the mentality of the governing coalition (Sárközy 2012). In reality, the reason for this distancing had more to do with the fact, that the economic supporters of the new government did not enjoy the sort of access to information and knowledge of the functioning of the state administration - as highlighted by László Csaba - on the eastern markets - as did their predecessors. In this time the imports of agricultural products constantly grew (Petschnig 1995). In a coauthored article, Alexandr Buzgalin and Andrej Koganov (1992) highlight the immense difficulties in penetrating the Russian market of the day. Miklós Kun (2010) - a historian - corroborated this in an interview he gave about Russian markets. He suggested that western companies had been supporting local traders in the newly emerging post-Soviet nations, who had good contacts with influential people in order to be well informed about the relations and situations on the ground.

The Antall government's decision to deepen trade relationships with Germany made the situation of the struggling Hungarian companies even worse. They were unable to sell their products on the German market, because of their low quality. To use a metaphor: it is easier to turn small ships in a narrow straight or bay in the direction of the wind, than it is turning a three mast giant. If we identify the narrow straight as the changes caused by the system change, than it is easier to see why newly emerged small entrepreneurs like Mr. Stadler - the little ships - had an easier time navigating the waters than humongous post socialist mammoth companies - three mast ships. The Antall government provided export subsidies to companies that were willing and capable of exporting. They provided agricultural exporters with a $30 \%$ cash-back subsidy of the prices of their exports. Entrepreneurs received 15-20\% back on clothes and other consumer products (Juhász - Mohácsi 1995).

Comparing police interviews and the article of journalist József Ballai, it seems that Ballai's account of Mr. Stadler's initial success is very accurate. ${ }^{20}$ Stadler LLC started off with a small fleet of trucks, however by 1993-94 the company "owned 42 - mostly Mercedes-Benz - bobtail trucks" (Ballai 2001a). At the time, the company made an export profit of 125 million dollars. Owing to Mr. Stadler's good contacts, his partners paid him in USD. In comparison to his profits from abroad, his one billion forint profit from the domestic Hungarian market seemed only like peanuts. At the exchange rate of the day, the 125 million profit made from exports equaled several tens of billions of forints. On the books, however Stadler LLC only showed a modest profit of 600 million forints. This meant that the company only had to pay corporate and other taxes after this amount.

At first, APEH - the Hugarian tax authority - only asked him questions about his company's inventory register, since he could never give an exact answer when asked how large his inventories were. When asked about his fruit concentrates and beer inventories, he always said, that he had X number of pallets, however he could not say how many bottles that meant in total. ${ }^{21}$ József Lovas, a decetive of the Kecskemét Police Department's property protection department conducted several covert investigations against Mr. Stadler, however there was never enough evidence to start conducting an overt investigation against the entrepreneur. In the Imrédy autobiography of Mr. Stadler, the entrepreneur makes mention of Detective Lovas, remembering how he would always call him into his office, and ask how he was able to make such immense profits (Imrédy 2008). It should be noted, that there is no proof as to the truth of this claim by Mr. Stadler, based on the interviews conducted with police detectives.

As the above cited figures show, Mr. Stadler's profits would have easily allowed him to pay the larger tax burdens, however he wanted a larger empire and he wanted it fast. ${ }^{22}$ In order to achieve his goal, he used a double invoicing system. The lot numbers, dates, company information were exactly the same. Only the unit and final prices differed. He provided the tax authority with the invoice with the larger prices, in order to receive larger export subsidies. In other

20 Interview with "B. M." police colonel 2013. 02. 24.

21 Interview with "K.F." retired police major, 2013.03.12

22 Interview with "B. M." police colonel 2013. 02. 24. 
words, he received the subsidies after much larger - fictive - sales. This, and not the VAT fraud he committed, was the real source of his immense profits. ${ }^{23}$ If we look at Stadler LLC's books, we can easily see, that the non-fraudulent export subsidies that would have been due to the company after the actual sales prices, would have covered Mr. Stadler's costs and left him with a significant profit - approximately a third of what he made by his cooking of the books. ${ }^{24}$

\section{The Macro Economical Effects of the Methods Used}

The only issue Mr. Stadler had to deal with because of his double invoicing scheme was that of the fictional profits his company was generating on paper - and thus the surplus taxes that he would have had to pay after these. In order to avoid paying these taxes, the accountant of the company, Gyula Hrubi, recommended generating surplus overhead costs and fictional losses, in order to eat-up the "balloon profits". ${ }^{25}$

This is how other organized crime syndicates appeared around Mr. Stadler. Nándor Pergel, a well tailored criminal, who spoke good French, and was involved in a horde of economic crimes, specialized in creating phantom companies in order to commit massive VAT fraud operations. ${ }^{26} \mathrm{His}$ air-conditioned car at the beginning of the $90 \mathrm{~s}$ gives a strong indication as to his financial situation. László Zsíros was one of Pergel's affiliates, in charge of accounting and phony invoicing. László Domák - or "Cinóber" as he was known - came from the world of prostitution and drug trafficking. He was shot dead on Üllöi road - in the heart of Budapest - in 1996. ${ }^{27}$

These men were "hardened criminals"28, compared to Stadler, however they were willing to take the entrepreneur from Akasztó onboard as an accomplice in the VAT fraud that they had already been conducting beforehand, since they saw potential in Mr. Stadler. They hoped to increase their profits and expand beyond mere VAT fraud through their newfound ally.

This ring of criminals mainly specialized in "transiting" products through Hungary. One company would import 155 288 pieces of cosmetic items for 971 thousand forints, which it sold on to a second company for 41 million forints. This company then resold the items for 20 million forints. The third company then sold the items for 147.5 million to the fourth, which sold the items to Mr. Stadler's company for a few million more. Of course, the VAT was refunded by the tax authority to Mr. Stadler's company in Akasztó. However, József Balla's - the journalist chronicling Mr. Stadlers activities claim that the VAT refund was the centerpiece of the illicit activities, is largely false. The above mentioned cosmetic items consisted of cheap French perfumes, and artificial leather shoes from Syria, manufactured for the dead - thus they were not of very high quality. ${ }^{29}$ The above described process of "transiting" happened through nonexistent companies - that were unknown to the business registry court. Physically the imported items went right to Mr. Stadler's warehouse in Akasztó, for less than one million forints. After the "transiting" had taken place, Stadler LLC resold the stock to Ukrainian and Romanian companies for a little more than the purchase price. This meant, that he had his initial investment returned, and he could show a huge loss towards the tax authorities, which meant that the company's yearly profits would fall accordingly, and thus Mr. Stadler would have to pay less taxes. ${ }^{30}$

In order to unravel the process of "transitioning" the authorities had to prove that the companies involved did not exist. They succeeded in doing so. They also managed to prove that all the invoices were written with Nándor Pergel's typewriter. ${ }^{31}$

Part of the aforementioned illegal mechanisms can be attributed to the 1994 IX. Act, which introduced "dereliction to provide economic data" as an offense into the Penal Code. Michael Toth's statement that "legislators were perhaps a little late" to respond to the challenges of the new world seems a bit mild, with the usage of hindsight. Nonetheless it was an important milestone in the criminal prosperity of "illegally wealthy and partially lost or forever changed peerless business enterprises" (Tóth 2000: 232). The purpose of the law was clear: increase the public legitimacy of companies in the eyes of criminal law.

\footnotetext{
${ }^{23}$ Interview with "B. I." retired police colonel 2013. 03. 31.

24 Interview with "B. M." police colonel 2013. 02. 24.

25 Interview with "B. M." police colonel 2013. 02. 24.

26 Interview with "B. M." police colonel 2013. 02. 24.

27 Interview with "N. L." retired police colonel, 2013. 04. 17.

28 Interview with "B. I." retired police colonel 2013. 03. 31.

29 Interview with "B. I." retired police colonel 2013. 03. 31.

30 Interview with "B. M." police colonel 2013. 02. 24.

31 Interview with "B. M." police colonel 2013. 02. 24.
} 


\section{The Media and the Political Impact of the Case-Stadler}

Another activity conducted by Mr. Stadler in order to increase his company's overhead costs shows just how easy it was for those involved in exporting to bamboozle even the authorities, which were unaware of many of the loopholes. In the interim period - between Mr. Stadler's moved from domestic business to exporting - the entrepreneur used the political and economic commotion to his advantage. He framed himself, as if he intended to do business with another emerging market economy, with similar endowments as Hungary. Various different Russian marketing agencies conducted marketing and market research activities for Stadler LLC in segments of the economy to which Mr. Stadler had no formal ties, but which he informally was very well acquainted with. The prosecution makes mention of seven invoices. These amounted to 2.4 billion in costs, which meant that the entrepreneur from Akasztó could decrease his tax base by 989.5 million in the year in question alone.

The majority of the media focused on Stadler the collector, since this was more tangible than the above described processes. It was something that could be presented in an entertaining and shocking story - well sellable in the media. In 1993, on paper Mr. Stadler bought 22 paintings - among which was The Last Supper, by Leonardo Da Vinci. Of course, it goes without saying that the $X V^{\text {th }}$ century fresco is located on the wall of the Santa Maria delle Grazie church in Milan and that art historians know of no original copy in existence. However, some art historians do claim, that in the XVII ${ }^{\text {th }}$ century, many painters did make canvas copies of the original. This claim was brought up several times by the defense attorneys of Mr. Stadler, as a mitigating circumstance, as Stadler could not have known if he was buying an original or not. Another peculiar item on the list of paintings bought by Stadler, were nudes painted by Mihály Munkácsy. According to art historians, Munkácsy never painted any nudes... Mr. Stadler paid for the lot of paintings in two installments - in cash in both cases. The joint tally of the two invoices came to 820483600 forints - this meant a VAT rebate of 205120900 forints. ${ }^{32}$

Stadler conducted his purchases for his collection through a certain Sergei Antoljevics Vexler - a Russian businessman. The authorities never found out who this person really was. As Stadler's defense argued that the fact that they could not find the man in question, was most likely due to the fact that Vexler is an extremely common surname. According to the invoices, Stadler bought the paintings from the ArtLux Gallery. The difficulties in inter-country justice assistance are well portrayed through the Vexler question. At first, Russian authorities admitted that the gallery in question did exist, and they claimed that a number of the paintings in question were stolen. Later on, however, as the case started gaining momentum, the Russian authorities denied the existence of the gallery, and the paintings as well. In the end, a Hungarian detective has to go to Moscow, to ascertain the existence of the gallery, and the companies behind it. Despite all the initial difficulties, in the end the cooperation of the Hungarian and Russian authorities proved that that none of the companies that Mr. Stadler conducted business with in Russia, actually existed. ${ }^{33}$

The founding of Stadler FC - football club - and the building of a stadium was another topic that the media took interest in. The case detectives mentioned their shock when they found Mr. Stadler sitting amidst lavish luxury in a gold plated room. His stadium and his other properties were often home to extravagant parties, where he invited people of power and influence as well as prostitutes, who he provided with copious amounts of extravagant free food and drink. ${ }^{34}$

One could only speculate at the actual extent of Mr. Stadler's political connections, until Magyar Nemzet - a Hungarian daily - published (on the $22^{\text {nd }}$ of February, 2001) a handwritten letter from Stadler, in which he asks Csaba Hámori and Ernő Balogh - two members of the Hungarian Socialist Party - to return at least twenty-thirty million forints to him of the amounts that he paid them earlier, so that he - Stadler - could finance his legal expenses (Molnár 2001). Géza Deésy, a member of the FKGP party, and a co-defendant of Stadler was accused of helping the entrepreneur deal in dubious perfumes. As Dessex LLC - Deésy's company - neglected paying VAT, Stadler, the customer, received a reimbursement from the State. The third degree co-defendant of the case first gave an explicit and in-depth confession, but later recanted, citing physiological pressure by interrogators - one of who is an interview subject of mine, cited in this article. However, from his initial confession, we can find out, that Géza "moneymaker" (Ballai 2001b) Deésy was approached by the criminal ring, because of his extensive informal contacts. Deésy in turn, was supporting himself, and his party's coffers from the illicit earnings. Although it should be mentioned that these charges were not proven in a court of law. Still, it is interesting to see how this dynamic contributes to the XXth century version of Lajos Leopold's (1988) fake capitalism theory: the usage of informal networks financially benefits the political elites. This may be one of the reasons that Claus Offe (1991) claims, that the transition to market economy in Central-Eastern Europe is primarily a

32 Interview with "N. L." retired police colonel, 2013. 04. 17.

33 Interview with "B. M." police colonel 2013. 02. 24.

34 Interview with "B. M." police colonel 2013. 02. 24., Interview with "K.F." retired police major, 2013.03.12 
political endeavor.

\section{Stadler, as a Brand Name}

The Stadler case was the first instance in post-socialist Hungary, when a defendant could use the media to his advantage, thus putting pressure on the authorities from the Parliament as well. This proves that the battle for the media has to be won as well. In 1998, the court instructed the investigative authorities to conduct a new investigation. The initial first degree court verdict sentenced Mr. Stadler to 9 years of incarceration and the confiscation of all his property. In 2003, the second verdict, resulting from the new investigation sentenced Mr. Stadler to 4 and six months, without substantially changing the findings of the first degree court. The justification of the court for commuting the sentence was Mr. Stadler's bad health, and the fact that he has already been undergoing criminal proceedings in excess of 10 years (Index 2003). The second degree co-defendant of Mr. Stadler, Gyula Hrubi was sentenced to three years in prison, three years of banning him from practicing public citizen's rights, and a fine of 200.000 forints. The fourth degree co-defendant, Géza Deésy received three years in jail, for continued fraud and forgery of private documents.

Stadler LLC was liquidated by the tax authority, since it did not pay several outstanding tax bills. When it was eliminated, it had a debt of approximately 9 billion forints (Balai 2005). Corvin Bank, one of the most important credit sources of the company never recovered the money that it lent Stadler LLC - which amounted to several billion forints, after late fines, and interest. ${ }^{35}$

After being released from prison, the ex-entrepreneur opened a shop in Solt, where he conducted commercial activities. Owing to his prior conviction, he was prohibited by law from taking up a leading role in any company, so his second and third degree accomplices were registered as the chief executives of the company (Origo 2011). During the investigative phase of his second case, Mr. Stadler admitted that he founded and held majority ownership in two companies. However, he also claimed that because of his prior conviction, he did not take an active role as an executive. He claimed that his second and third degree accomplices fulfilled their duties as executives. The two companies were registered at the homes of the two accomplices; however the actual offices of the companies were in Solt. During the 2008 economic crisis, Mr. Stadler was utilizing his vast network of acquaintances to buy up clothes and foodstuffs below market prices in eastern countries, and import them to Hungary. He also bought unpackaged detergents in massive amounts at wholesale prices, packaging and branding the detergent under his own name (Index 2007). He bought the secondhand clothes in massive quantities as well, and resold selected pieces to the residents of Bács-Kiskun County as new.

The tactics used by Mr. Stadler during the 90s became successful once again in the 2000s, in large part due to the economic crisis. Mr. Stadler had more customers, and more illicit business associates than ever. According to the prosecution, between 2007 and 2010, Mr. Stadler caused 420 million forints worth of damages to the Hungarian State by issuing and accepting fraudulent invoices through companies in which he had interests, in order to apply for VAT refunds, in order to make illegal profits or decrease the tax burdens of his companies. The Szeged Appellate Court sentenced Mr. Stadler to 4 years and 10 months incarceration, and confiscation of property worth 67 million forints in November of 2011. According to the investigation materials, he bought the massive amounts of clothes from Western-Europe without providing invoices, and then with the help of his previous accomplice, Gyula Hrubi, he proceeded to produce fraudulent invoices to non-existent companies, claiming to have bought the clothes from them. However, since these companies were non-existent, they did not pay VAT. However, Mr. Stadler was able to apply for VAT reimbursement himself. It was suspected, that the clothes made their way to Eastern Europe by way of charity organizations, which illegally sold the clothes to Stadler and other criminal organizations. Since clothes arriving to Hungary from charity organizations could not be resold through commercial activity, it was necessary for Mr. Stadler to produce a paper trail. On paper he bought the detergents and other accessories at such a high price that he could again, write off some of his corporate tax base (Origo 2011).

With his trademark shout of "I am innocent" (Blikk 2005) and with his attacks on politicians, Mr. Stadler became successful in the media. Law enforcement officials that were socialized during totalitarian socialism were most likely puzzled by the fact that Mr. Stadler became a favorite of the newly privatized media outlets. Various newspapers and magazines helped create the image of a folk hero (Index 2011). This was something that could not have happened in the time of state run media only a few years earlier. From sheepherder to billionaire entrepreneur: a real self made man. Since Mr. Stadler, the authorities take it for granted that cases have to be won not only in the court, but also in the

35 Interview with "B. M." police colonel. 2013. 02. 24. 
media. ${ }^{36}$

Mr. Stadler was already a successful businessman during socialism. At the time of the system-change in Hungary through his extensive network of contacts he was capable of selling products that seemed unsellable at the time. By organizing the shipping activities himself, Stadler was able to extend his range, and his profits - through illicit activities. Mr. Stadler took advantage of raking in cash from criminals, looking to invest money attained through illicit enterprises into legal activities - something that was done regularly, as pointed out by Dános and Kacziba. However, the case of the entrepreneur from Akasztó is special, insofar as his criminal career took off, as a result of the legal uncertainties surrounding the system change of 1989, through the various semi-legal and illegal activities described above. The man that had gotten away with his illegal activities during socialism thanks to his good informal connections, used this advantage to start exporting to eastern markets following the system change. By accident or owing to political pressure, the media often portrayed him as a folk hero, which facilitated a faulty perception of the wider public of Mr. Stadler. ${ }^{37}$ Nevertheless, the fact remains, that József Stadler was one of the most successful entrepreneurs of the system change.

\section{Bibliography}

Interviewes:

Interview with "N.L." retired police colonel, 2013.04.17.

Interview with "B.I." retired police colonel, 2013.03.31.

Interview with "K.F." retired police major, 2013.03.12.

Interview with "B. M." police colonel 2013. 02. 24.

\section{References}

Ambrus S., (1995): Stadlerakasztó. Pilvax Publishing Co., Budapest.

Ballai J., (2001a): A Stadler-dosszié - I. rész: A búsuló juhász. Magyar Narancs 2001. 02. 01. (http://magyarnarancs.hu/belpol/a_stadlerdosszie_-_i_resz_a_busulo_juhasz-62501)

Ballai J., (2001) magyarnarancs.hu/belpol/stadler_jozsef_vadlott_levele_az_mszp-nek_az_utolso_vicsora-61342)

Ballai J., (2005): Stadler József szabadon: Korunk hőse. Magyar Narancs, 2005. február 3. http://magyarnarancs.hu/belpol/stadler_ jozsef_szabadon_korunk hotildese-53283

Barnóczki B. - Prókai E. (2012): Az első utcai kivégzéstöl a leghírhedtebb robbantásig. Origo, 2012. július 18. (http://www.origo.hu/ itthon/20120717-a-kilencvenes-evek-robbantasai-merenyletei-es-az-olajugyek.html)

Böröcz J. (1992): Kettös függőség és tulajdonvákuum: Társadalmi átalakulás az államszocialista félperiférián. Szociológiai Szemle, 2 (3.), 3-20.

Buzgalin, A. -Koganov, A. (1992): Totális privatizáció - méreg és orvosság (Tézisek) In: A jelcini gazdaságpolitika alternatívái. Szakértői jelentés. Szovjet Füzetek VI. Magyar Russzisztikai Intézet, Budapest.

Castells, M (2007): Az évezred vége. Az információ kora. Gazdaság, társadalom és kultúra III. kötet, Gondolat, Budapest.

Csaba L. (1999): A szovjet modell összeomlása és a rendszerváltozás első szakasza. Valóság, 42. (11.) 24-43.

Csaba L. (1991): Tanács-talanul a keleti piacon. Társadalmi Szemle, 46. (6.), 3-16.

Csaba L. (1992): Volt-e sokkterápia Oroszországban? In: A jelcini gazdaságpolitika alternatívái. - Szakértői jelentés. Szovjet Füzetek VI. Magyar Russzisztikai Intézet, Budapest.

Diós Erzsébet (2009): Bankcsődök és bankárperek: bankbukások története tanulságokkal. OKRI Szemle (eds.: Virág Gy.). 81-100.

Dunagate-report. (1990. January 16.) (2015) Belügyi Szemle 63. (1.) 42-58.

Elvirát a börtönböl hódította meg Stadler. Blikk, 2005. 21th of January. http://www.blikk.hu/blikk_aktualis/20050121/elvirat_ a_bortonbol_hoditotta_meg_stadler

Felértékelödnek a keleti piacok (2010). Interjú Kun Miklóssal 14th of July (http://szegedma.hu/hir/szeged/2010/07/felertekelodnek-akeleti-piacok.html)

Fekete Gy. A. (2009): A magyar nyomkeresők bealszanak a CSI-on. Népszabadság 2009. 28th of November (http://nol.hu/lap/ hetvege/20091128-nyomkeresok)

Fekete Gy. A. (1995): Gazdasági büncselekmények - milliárdos károkkal. Népszabadság, 1995. 9th of January. 1.

Goldman, Marshall I. (1997): Why is the Mafia so dominant in Russia? Challenge 39. (1.) 39-47.

Imrédy P. (2008): A Stadler story 1. kötet A kisjuhásztól a nagy felvásárlóig. Kastély-Bor Kft., Akasztó.

Ismét börtönre ítélték Stadler Józsefet. Origo, 2011. november 17. http://www.origo.hu/itthon/20111117-jogerosen-negy-ev-tiz-honapbortonbuntetessel-valamint-67-millio-forintos.html

Javlinszkij, G. A. (1993): Uroki ekonomicseszkoj reformi. Eplcentr, Moszkva.

${ }^{36}$ Interview with "B. M." police colonel 2013. 02. 24.

${ }^{37}$ Interview with "N.L." retired police colonel, 2013.04.17 
Jávor I. (2011): Korrucpiós mechanizmusok a magyar bírósági eljárásban. Társadalomkutatás, 29. (2.), 247-267.

Jávor I. - Rozgonyi T. (2005): Hatalom - Konfliktus - Kultúra. KJK-Kerszöv, Budapest.

Jávor I. - Jancsics D. (2012): Korrupció a bíróságon és a gazdaságban. Kriminológiai Közlemények 70. 212-245.

Juhász P. - Mohácsi K. (1995): Az agrárágazat támogatásának néhány összefüggése. Közgazdasági Szemle, 42. (5.) 471-484.

Dr. Kacziba A. (1996): A gazdaság, a fekete gazdaság, a gazdasági szervezett bánözés és a korrupció. In: Domokos Andrea (eds.): Kriminológiai Közlemények 54.

Korinek L. (2015): Rendszerváltozás a belügyben. Belügyi Szemle. 63. (1.) 5-33.

Kovács É. (2007): Interjús módszerek és technikák. In: Kovács Éva (eds.): Közösségtanulmány - módszertani jegyzet. Néprajzi Múzeum, Pécs. 269-277.

Krausz T. (2003): A peresztrojka és a tulajdonváltás. Politikai koncepciók és történelmi valóság. In: Krausz Tamás (szerk.): Presztrojka és tulajdonáthelyezés. Tanulmányok és dokumentumok a rendszerváltás történetéböl a Szovjetunióban (1985-1991). Magyar Ruszisztikai Intézet.

Ifj. Leopold Lajos (1988): Színlelt kapitálizmus. Medvetánc, 8. (2-3.) 321-355.

Losonczi Cs. - Magyar G. (1996): Pénzügyek a gazdaságban. Juvent Kiadó, Budapest.

Molnár P. (2001): Stadler-gate az MSZP-ben. Rendör ezredes is tanúsítja a párt 1994-es „szponzorálását”. Magyar Nemzet, 2001. 24th of February. http://mno.hu/migr_1834/stadlergate-az-mszpben-843872

Mong A. - Vajda É. (2009): Az ártatlanok kora. Elektromédia, Budapest.

Négy év hat hónap Stadlernek Index 2003. 12th of February http://index.hu/bulvar/stadler0212/

Offe, C. (1991): Az egyidejüség dilemmája. Demokratizálás és piacgazdaság Kelet-Európában. Társadalmi Szemle, 46. (8-9). 113-122.

Paládi J. (1988): A zöldséges maffia. Népszava, Budapest.

Minutes of the Parliementary investigative committee created to investigate any possible links between the oil business and organized crime. 2000. 10 o'clock Monday, October the 30th, meeting held at meeting room number 61 of the Parliament, accessible online at: last download: 2013.05.15 http://www.parlament.hu/biz36/olaj/v006-021.htm

Petschnig M. Z. (1995): Túl az első fél éven. A pangó piac nem ígér változást. In: Kéri L. - Petschnig M. Z.: 24 évszak. Intera Rt., Budapest.

Ponton, G. (1994): The Soviet Era. Soviet Politics From Lenin to Yeltsin. Blackwell Publishers, Oxford, 1994. 132-133.

Raddaway, P. - Glinski, D. (2001): The Tragedy of Russia's Reforms: Market Bolshevism against Democracy. US Institute of Peace Press, Washington D. C.

Rosenthal, G. (2006): The Narrated Life Story: On the Interrelation Between Experience, Memory and Narration. In: Kate Milnes Christine Horrocks - Nancy Kelly - Brian Roberts - David Robinson (eds.): Narrative, Memory \& Knowledge: Representations, Aesthetics, Contexts. University of Huddersfield, Huddersfield, 2006. 1-16.

Rossiiskaya maffia sobiraet dos'ye na krupnykh chinovnikov i politikov. Izvestiya. 26th of January 1994. pp1-2.

Sárközy T. (2012): Magyarország kormányzása 1978-2012. Park Könyvkaidó, Budapest, 2012.

Stadler: eredeti a Hámori-levél. Index, 2001. 22th of February. (http://index.hu/belfold/stadlermszp/)

Stadler válasza az Armanira. Index, 2007. 4th of November. http://index.hu/video/2007/11/04/stadler_valasza_az_armaniral

Sik E. (2012): A kapcsolati töke szociológiája. ELTE-Eötvös Kiadó, Budapest.

A sírból hozná vissza az akasztói stadiont. Index, 2011. 17th of November. http://index.hu/video/2011/11/17/stadler_stadion/

Szelényi Iván (1995): Menedzser-kapitalizmus. Lettre. 4. (19). (online: http://epa.oszk.hu/00000/00012/00003//szeleny2.htm) (last download: 2013. 05. 02.)

Szelényi I. -Eyal, G. - Townsley, E. (1998): A posztkommunista gazdasági vezetés (menedzserizmus). A gazdasági intézmények átformálása és a társadalom szerkezetében végbemenő változások a posztkommunista átmenet idején. In: Krausz Tamás (szerk.): Rendszerváltás és társadalomkritika. Napvilág Kiadó, Budapest. 153-193. 0.

Dr. Tóth Mihály (1995): Piacgazdaság és büntetőjog In: Lévay Miklós (szerk.): Kriminológiai Közlemények 52. Magyar Kriminológiai Társaság, Budapest. 4-23.

Tóth Mihály (2000): Gazdasági bünözés és büncselekmények. KJK-Kerszöv, Budapest.

Több mint négy év letöltendö börtönt kapott Stadler József adócsalásért. Origo, 2011. 16th of May. http://www.origo.hu/itthon/20110516stadler-jozsef-tobb-mint-negy-ev-letoltendo-bortont-kapott-elso.html

Zelei M. (1990): Még egy kis Ambrusológia. Beszélö, 5. (1.) 3. 
